
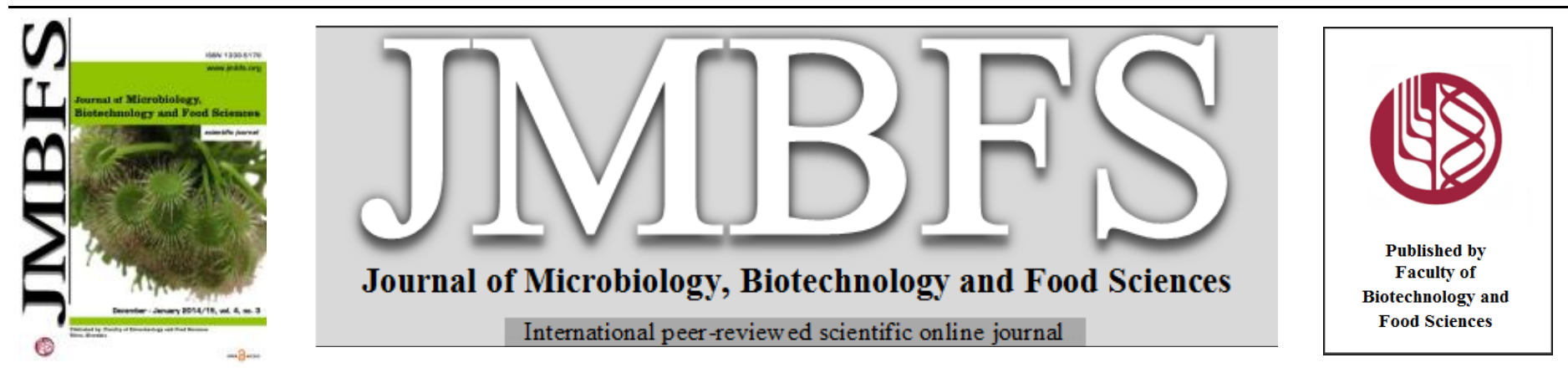

\title{
GENETIC DIVERSITY AMONG YERSINIA ENTEROCOLITICA ISOLATED FROM SEWAGE, RAW MILK AND PACKED FOODS
}

\author{
Shanmuga Priya Seshadhri, Thayumanavan Thangavelu* and Senthil Murugan Thangavel
}

Address(es): Dr. G.R. Damodran,

College of Science, Department of Biotechnology, Coimbatore-641 014, Tamil Nadu, INDIA.

*Corresponding author: thayumanavan@yahoo.com

doi: $10.15414 / j m b f s .2014-15.4 .3 .271-276$

\section{ARTICLE INFO}

Received 19. 4. 2014

Revised 6.11.2014

Accepted 6. 11. 2014

Published 1. 12. 2014

Regular article

open $\partial$ access

\begin{abstract}
A total of 90 isolates (40 from sewage, 30 from raw milk and 20 from packed foods) collected to study the incidence of Yersinia enterocolitica. It was observed that 61 isolates ( 32 from sewage, 19 from raw milk and 10 from packed foods) were found contaminated with the bacterium. All the isolated strains were confirmed to Yersinia enterocolitica, by using $16 \mathrm{~S}$ rRNA PCR. Of 61 strains, only five strains (two from sewage and two from packed foods and one from raw milk) were found to be the producers of haemolysin at $37{ }^{\circ} \mathrm{C}$, while among the five strains only two strains from packed foods produced haemolysin at $28{ }^{\circ} \mathrm{C}$. All the isolates showed resistance to amoxicillin and found sensitive to chloramphenicol. Seven strains were producer of High molecular weight proteins (HMWP). 53 strains have produced rough LPS, while the smooth LPS has been observed for 8 isolates. Eleven and six different profiles observed in outermembrane proteins and lipopolysaccaride respectively. Combined primer 1 and 2 RAPD-PCR dendogram shows eight different genotypic patterns.
\end{abstract}

Keywords: $Y$. enterocolitica, haemolysin, multiple antibiotic resistances Outer membrane protein, Lipopolysaccaride, RAPD-PCR

\section{INTRODUCTION}

Yersinia enterocolitica is a Gram-negative bacterium, belonging to the family Enterobacteriaceae that causes food-transmitted infections (Keet, 1974; Eden $\boldsymbol{e}$ al., 1977). The Common clinical syndromes include gastroenteritis, various forms of abscesses, septicemia, arthritis, mesenteric lymphadenitis and erythema nodosum (Bottone, 1977). This microorganism has been isolated from water, dairy products, foods, animals and humans in various country where isolation has been attempted (Bottone, 1983, Shayegani et al., 1983). Y.enterocolitica is rapidly emerging worldwide as an enteric pathogen and has become a major cause of diarrhea in most of the industrialized world. $Y$. enterocolitica may present in various raw animal foods and causes illness when consumed by human beings. As bacterium can survive at $4^{\circ} \mathrm{C}$, so it can grow well in refrigerated foods and survive in frozen foods for long periods. To control and treat the infectious diseases, antimicrobial susceptibility test were used (Phillips et al., 2004). The outer membrane protein (OMP) of the $Y$. enterocolitica is probably involved in the host - bacterial interactions; Because OMP is dependent on the presence of plasmid for expression (Zink et al., 1980) Protein level typing mostly determines the pathogenic species diversity. RAPD PCR (Random Amplification of Polymorphic DNA) directs a random DNA sequence by using a single primer (Bottone, 1997). Considering the significance of water or food-borne illness and genetic diversity of this bacterium this study has been taken to analyze the antimicrobial resistance, haemolysin activity, LPS, OMP and RAPD-PCR among the contaminated water, raw milk and packed foods.

\section{MATERIAL AND METHODS}

\section{Sample collection and isolation}

A total of 90 isolates, (comprises 40, 30 and 20 from sewage, raw milk and packed foods respectively) were collected from different locations during winter seasons, mainly in and around Coimbatore, Tamil Nadu. One $\mathrm{ml}$ of sewage water, milk samples and $0.1 \mathrm{~g}$ of packed food samples were inoculated into $10 \mathrm{ml}$ of yersinia enrichment broth (Hi Media, India) and incubated at $30{ }^{\circ} \mathrm{C}$ for $24 \mathrm{~h}$ Then a loopful of culture was transferred and streaked on to Yersinia selective agar (CIN agar) (Hi Media, India), followed by incubated at $28{ }^{\circ} \mathrm{C}$ for $18-24 \mathrm{~h}$ After incubation, the plates were analyzed for red bull's eye shaped pinpoint colonies.

\section{Confirmation of $Y$. enterocolitica}

All the isolates were subjected to ten biochemical methods (Voges-Proskauer, urease, sorbitol, ornithine decarboxylation, citrate, DNase, raffinose, esculin hydrolysis, salicin fermentation and lysine iron agar (LIA)), according to Bergey's Manual of Systematic Bacteriology. (Table.2). Further the isolates were identified as $Y$. enterocolitica by PCR based on 16S rRNA gene amplification as described by (Neubauer et al., 2000).

\section{Hemolytic activity}

All the isolates $Y$. enterocolitica were individually enriched in $5 \mathrm{ml}$ of brain heart infusion broth (BHI, Hi Media, India) and incubated at $37{ }^{\circ} \mathrm{C}$ for $16-18 \mathrm{~h}$. Supernatant fluids were carefully removed after centrifugation at $10,000 \times \mathrm{g}$ for $30 \mathrm{~min}$ at $4{ }^{\circ} \mathrm{C}$. About $100 \mu \mathrm{l}$ of supernatant fluids were mixed with an equal volume of $2 \%(\mathrm{v} / \mathrm{v})$ suspension of rabbit erythrocytes in a 96-well 'V'-bottom microtitre plate. The mixture was incubated for $30 \mathrm{~min}$ at $37^{\circ} \mathrm{C}$ and then for 30 min at $4{ }^{\circ} \mathrm{C}$. An erythrocyte suspension in phosphate-buffered saline (PBS) was included in each assay as a negative control. Haemolysin production was recorded by visual inspection (Table 3 ).

\section{Antimicrobial susceptibility test}

All the isolates were tested for their multiple antibiotic resistances against 21 different antibiotics (Table 4), using Mueller-Hinton agar (Hi Media, India) by adopting standard disc diffusion method (Bauer et al., 1966). Following disc diffusion all the plates were incubated at $28{ }^{\circ} \mathrm{C}$ for $24 \mathrm{~h}$. After the incubation periord, the diameter of the inhibition were measured and compared with the Performance Standars for Antimicrobial Disk Susceptibility Test CLSI (2012).

\section{Extraction of outer membrane protein (OMP)}

The $Y$. enterocolitica strains were grown in $20 \mathrm{ml}$ of Nutrient broth (Hi Media, India) overnight at $37{ }^{\circ} \mathrm{C}$. Preparation of OMP was done according to Winder $\boldsymbol{e t}$ al. (2000). The pellet containing the OMP was resuspended in deionised water (1 $\mathrm{ml}$ ) and stored at $-20{ }^{\circ} \mathrm{C}$ until required. The samples were subjected to $12 \%$ polyacrylamide gels containing SDS (SDS-PAGE) and the gel was stained with Coomassie brilliant blue R-250 (Laemmli UK, 1970) 


\section{Extraction of lipopolysaccaride (LPS)}

Cells were grown in nutrient broth for $48 \mathrm{~h}$ at $37^{\circ} \mathrm{C}$. LPS from cells was obtained by the hot phenol - water method (Rezania et al., 2011). Twenty $\mu$ l of LPS suspension was applied in each slot of $12.5 \%$ SDS - PAGE gel. The separated LPSs were visualized by silver staining (Tsai and Frasch, 1982).

\section{Random Amplification of Polymorphic DNA (RAPD) PCR}

The primer used in this study was primer 1 (5'-CCGCAGCCAA-3') and primer 2(5'-GAGACGCACA-3'). Each $25 \mu \mathrm{l}$ reaction mix contains $30 \mathrm{ng}$ genomic DNA, $1 \mathrm{U}$ Taq DNA polymerase, $1 \mathrm{X}$ Taq DNA polymerase buffer (Chromous Biotech, Bangalore), $2.5 \mathrm{mM} \mathrm{MgCl}$, $400 \mu \mathrm{MdNTPs}$ (Helini Biomolecules, India) and $20 \mathrm{pmol} / \mu 1$ primer. RAPD used for the study of diversity among $Y$. enterocolitica isolates was performed as described by Leal et al. (1999). RAPD data were coded, analysed, all molecular markers were combined in a final analysis. Each amplified product revealed by electrophoresis was recorded as binary data, presence (1) and absence (0): an initial matrix of 0 and 1 was constructed. The genetic similarities amongst isolates were calculated from the matrix data using the simple matching (SM) index (Duart et al., 1999). The cluster analysis was performed by mean of the unweighted paired group method using arithmetic average (UPGMA) (Saitou and Nai, 1987). The statistica robustness of the inferred tree was estimated by means of the cophenetic correlation coefficient (CCCr) (Duart et al., 1999), bootstrap, and best-cut test Dendrogram branches with bootstrap values higher than $50 \%$ and relationships on the right side of best-cut-test vertical line were considered significantly supported. All of these analyses were made with the NTSYS-PC software, version 2.02j (Duart et al., 1999) and PHYLIP ver. 3.6 software (Saitou and Nai, 1987)

\section{RESULTS AND DISCUSSION}

Environment is the most common source for $Y$. enterocolitica bacterium, than any other. Among the environmental sources, water is the most significant one. Incidence of the bacterium has been reported from freshwater such as rivers, lakes and drinking water (Langeland, 1983; Massa et al., 1988; Kuznetsov and Timchenko, 1998). They have also been isolated from sewage (Ruhle $\boldsymbol{e t}$ al. 1990; Ziegert and Diesterweg, 1990). Falcao et al. (2004) reported that $26 \%$ of the total isolates of sewage origin were found to be $Y$. enterocolitica. In our study, of the 90 samples collected, 61 were found contaminated with $Y$. enterocolitica (Table 1), which confirmed by using biochemical tests (Table 2) and 16S rRNA PCR. Maximum incidence of contamination was recorded for sewage samples was $80 \%$. This is most significant value with respect to the incidence of this bacterium. In another study, $36.6 \%$ of raw milk samples were positive for this organism (Hamama et al., 1992). Similarly, the incidence of $Y$. enterocolitica has been reported from raw milk samples as $20 \%, 81.4 \%$ and $10.6 \%$ by Franzin et al. (1984), Vidon and Delmas, (1981) and Subha et al. (2009) respectively. In our study, $64 \%$ of the raw milk samples were recorded as positive for this bacterium. Seventy six cheese curd samples tested, $9.2 \%$ were positive for $Y$. enterocolitica (Schiemann, 1978). It report $50 \%$ of packed foods samples were contaminated with $Y$. enterocolitica.

Table 1 Incidence of $Y$. enterocolitica in various samples

\begin{tabular}{lcc}
\hline Sample & No. of samples & $\%$ positive \\
\hline Sewage & 40 & $80 \%(\mathrm{n}=32)$ \\
Raw milk & 30 & $64 \%(\mathrm{n}=19)$ \\
Packed foods & 20 & $50 \%(\mathrm{n}=10)$ \\
\hline
\end{tabular}

Table 2 Biochemical results of various tests against the isolates

\begin{tabular}{lcc}
\hline Biochemical test $^{\mathrm{a}}$ & No. positive & \% positive \\
\hline Voges -proskauer & 75 & 83 \\
Urease & 73 & 81 \\
Sorbitol & 70 & 78 \\
Ornithine decarboxylation & 45 & 50 \\
Citrate & 65 & 72 \\
DNase & 46 & 51 \\
Raffinose & 61 & 68 \\
Esculin hydrolysis & 5 & 6 \\
Salicin fermentation & 5 & 6 \\
Lysine Iron Agar (LIA) & 61 & 68 \\
\hline
\end{tabular}

${ }^{\mathrm{a}} \mathrm{All}$ biochemical tests completed at $36^{\circ} \mathrm{C}$ unless otherwise noted

Haemolysin activity was carried out for all Y.enterocolitica strains. It showed that only $8 \%$ were found to produce haemolysis. Production of haemolysin is said to be one of the virulence factors among pathogenic microorganisms. However, based on the haemolysin production alone, one should not confirm the pathogenicity. Non-haemolytic isolates of $Y$. enterocolitica have also been confirmed as pathogens to human and animals (Subha $\boldsymbol{e t}$ al., 2009). Influence of temperature on activity of haemolysin was also studied. This bacterium shows haemolytic activity at $37^{\circ} \mathrm{C}$ and $28^{\circ} \mathrm{C}$ as well (Franzin $\boldsymbol{e t}$ al., 1984). Similarly in the present study for haemolytic activity, all five were found to carry out heamolysis at $37{ }^{\circ} \mathrm{C}$, while two isolates among them were able to produce haemolysin at $28{ }^{\circ} \mathrm{C}$ (Table 3 ). In a study conducted in Italy, of 131 Yersinia sp., 74 were positive for haemolysin production and also, they could lyse both RBCs of chicken and rabbit with $0.5 \%$ lecithin at $28{ }^{\circ} \mathrm{C}$ (Franzin et al., 1984) Phillips et al., (2000) reported that $Y$. enterocolitica could produce haemolysin at both the temperature $28{ }^{\circ} \mathrm{C}$ and $37{ }^{\circ} \mathrm{C}$. In contrast, Singh and Virdi (2004) reported that clinical isolates of $Y$. enterocolitica shows haemolytic activity at 37 ${ }^{\circ} \mathrm{C}$ at $\mathrm{pH} 7.5$, incubated for $144 \mathrm{~h}$. However, in our study, haemolytic activity was observed within $24 \mathrm{~h}$. This study clearly reveals the genetic diversity among the isolates.

Table 3 Haemolytic activity of $Y$. enterocoltica isolated from different sources

\begin{tabular}{lc} 
No. of strains & Haemolysin assay \% positive \\
\hline $61\left(\right.$ at $\left.28^{\circ} \mathrm{C}\right)$ & $3.27 \%(\mathrm{n}=2)$ \\
$61\left(\right.$ at $\left.37^{\circ} \mathrm{C}\right)$ & $8.19 \%(\mathrm{n}=5)$ \\
\hline
\end{tabular}

The increased resistance to various antibiotics poses a serious challenge to physicians in order treat microbial infections. Now-a-days, most of the organisms exhibit multi-drug resistance which may have been triggered due to the mechanism of horizontal gene transfer (HGT) which happens in natural environment. Antimicrobial resistance among food-borne pathogens and therapeutical intervention has always been an important issue in public health. It can be another reason for antibiotic resistance transfer to humans via the food chain (Ezekiel et al., 2011). In the present study, the 21 different antibiotics tested, it was observed that all the $Y$. enterocolitica were sensitive to chloramphenicol, while all the organisms showed resistance towards amoxicillin It was also observed that $98 \%, 80 \%, 55 \%, 80 \%, 79 \%$ and $82 \%$ of the strains were found resistant to ampicillin, erythromycin, gentamycin, kanamycin, piperacillin and tetracycline respectively (Table 4), which was very close to the findings of Yazdi et al. (2011).

Stock and Wiedemann, 1999; Okwari et al., 2007 reported $99 \% Y$. enterocolitica were resistant to amoxicillin from humans, animal and environment which was similar to our finding. Y. enterocolitica of milk origin were found reported to towards ampicillin and sensitive to chloramphenicol (Subha et al., 2009). In contrast, chloromphenicol resistant strains have been also been reported (Yazdi $\boldsymbol{e t}$ al., 2011), while for other antibiotics, controversy results have been recorded. This clearly indicates the impacts geographical locations and environment. This bacterium is well known for the horizontal gene transfer, through that, it may acquire these resistance genes and exhibited such kinds of character.

Table 4 Antibiotic susceptibility of Y.enterocolitica isolated from different samples

\begin{tabular}{lccc}
\hline Antibiotics & Disc potency $(\mu \mathrm{g})$ & Resistance & $\%$ Resistance \\
\hline Amoxicillin & 25 & 61 & 100 \\
Ampicillin & 10 & 60 & 98 \\
Amikacin & 30 & 24 & 39.3 \\
Chloramphenicol & 10 & 0 & 0 \\
Ciprofloxacin & 5 & 60 & 98 \\
Erythromycin & 15 & 49 & 80.3 \\
Gentamicin & 10 & 34 & 55.7 \\
Imipenam & 10 & 23 & 37.7 \\
Kanamycin & 30 & 49 & 80.3 \\
Methicillin & 10 & 4 & 6.55 \\
Nalidixic acid & 30 & 3 & 4.91 \\
Novobiocin & 30 & 15 & 24.5 \\
Oxytetracyclin & 30 & 2 & 3.27 \\
Penicillin G & $10 u n i t s$ & 57 & 93.4 \\
Polymyxin-B & $50 u n i t s$ & 5 & 8.16 \\
Piperacillin & 75 & 48 & 78.6 \\
Rifampicin & 5 & 13 & 21.3 \\
Streptomycin & 10 & 57 & 93.4 \\
Tetracycline & 30 & 50 & 81.9 \\
Tobramycin & 10 & 3 & 4.91 \\
Trimethoprim- & 10 & 8 & 13.11 \\
sulfamethoxazole & & & \\
\hline
\end{tabular}

The full expression of virulence due to $70 \mathrm{~Kb}$ pYV plasmid, which correlates with the massive release of a set of proteins (Yops) (Gemski et al., 1980). It became clear that pYV and Yops are essential for the pathogenicity of yersinia species including $Y$. enterocolitica (Bliska et al., 1991). In our study, five strains (S34, S46, S54, S55 and S58) are 1B biotype, which shows high pathogenicity among others. In general, the banding pattern of total and membrane proteins not very useful in distinguishing between strains because of the numerous bands 
displayed (Kwaga and Iversen, 1992). High molecular weight protein (HMWP) with a molecular weight of $150-220 \mathrm{kDa}$ determines pathogenic isolates. From 61 strains tested, we observed that three isolates (S34, S46 and S54) have produced similar kind of protein, which confirms the presence of high pathogenic strains among other isolates and eleven different banding patterns (Fig. 1). In another study the presence of both HMWP1 and HMWP2 are present in pathogenic strains of $Y$. enterocolitica (Schubert et al., 1998).
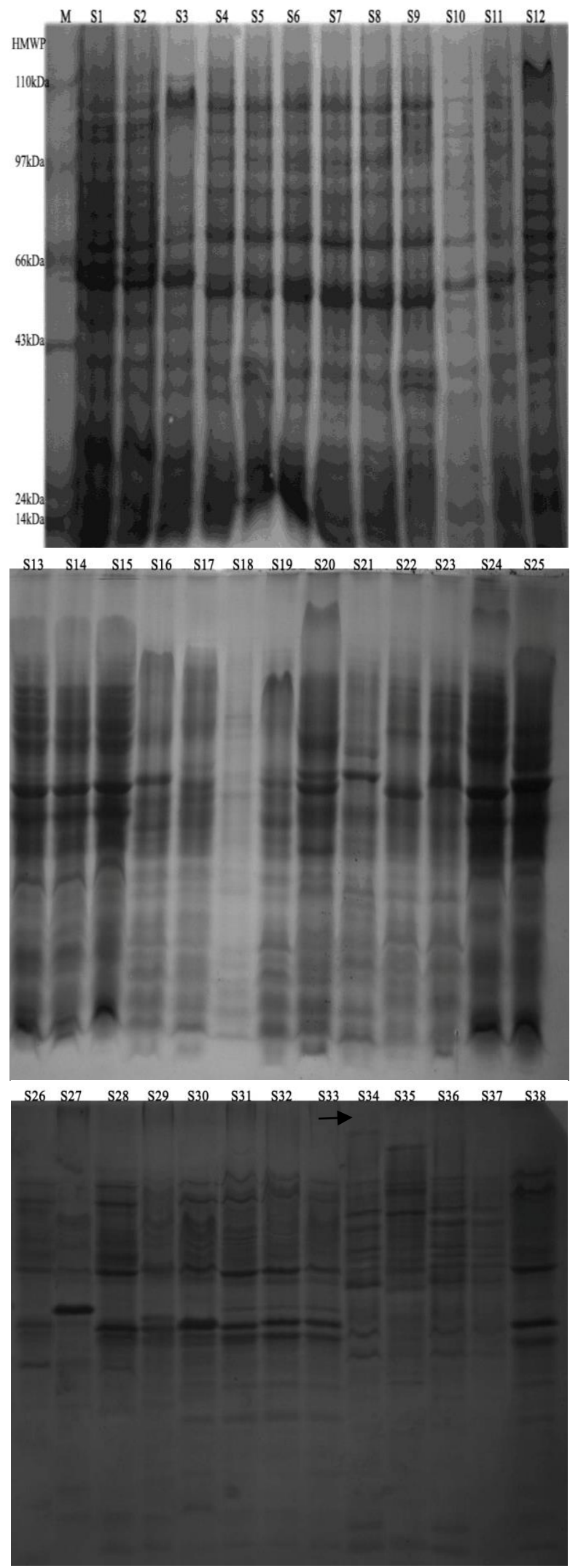
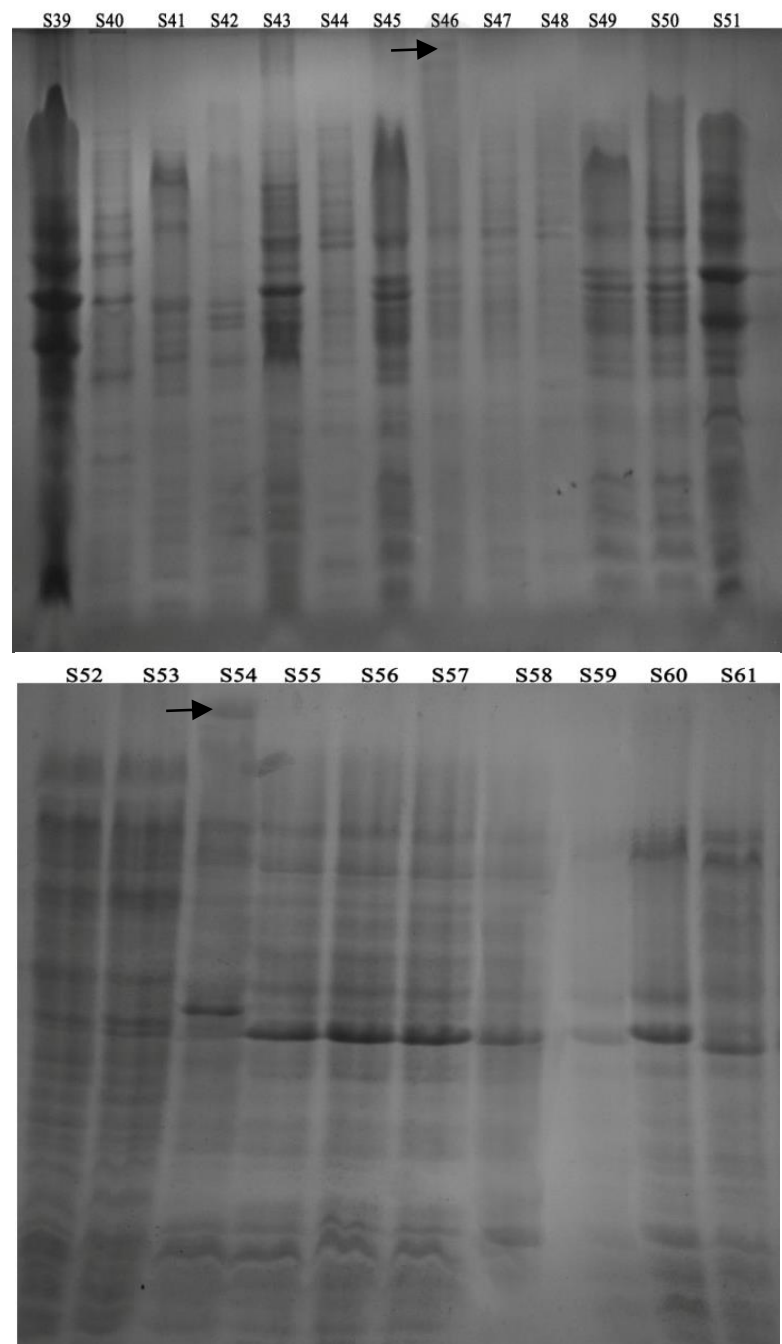

Figure 1 Outer membrane protein of isolated Y.enterocolitica

LPS is the major immunogenic component of the Gram-negative enterobacterium $Y$. enterocolitica. LPS has branched repeating pentasaccharide units, therefore, we observed the distinct repeating bands. $Y$. enterocolitica cultures incubated at 25 and $37^{\circ} \mathrm{C}$ differ in several characteristics. Pathogenic strains can be identified under the temperature of $37^{\circ} \mathrm{C}$, so we undergone the protein isolation in the same temperature. $Y$. enterocolitica bio-serotype 1B/O: 8 show pathogenicity when incubated at $37{ }^{\circ} \mathrm{C}$ in the absence of $\mathrm{Ca}^{2+}$ (Michiels et al., 1990). Severa investigators worked on the characterization of LPSs produced by $Y$. enterocolitica (Pai and Mors, 1978, Boyce et al., 1979, Francis et al., 1980, Zhang

et al., 1997). In our study, 53 strains have produced rough LPS, while the smooth LPS has been observed for 8 isolates only (Fig. 2). The isolates could be rough mutants that arose from an originally smooth isolate during in vivo passage (Kawaoka et al., 1986).

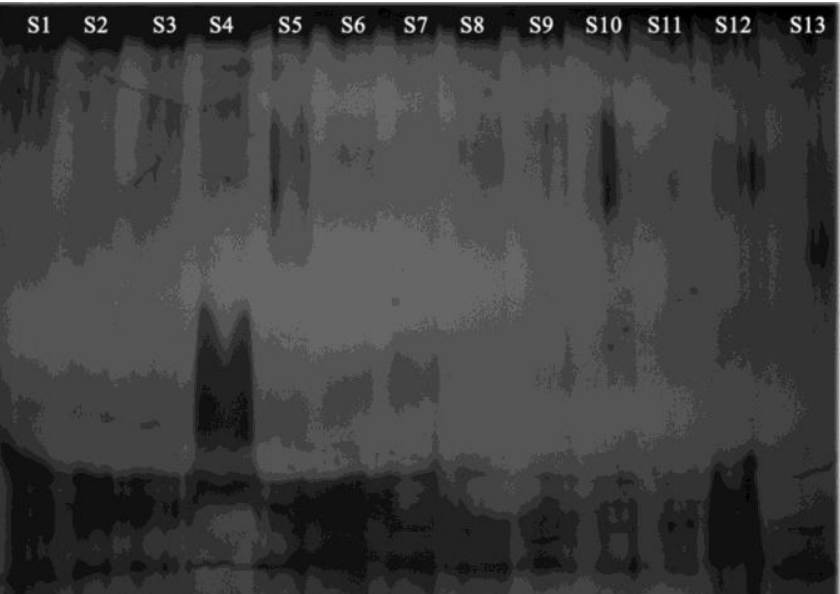



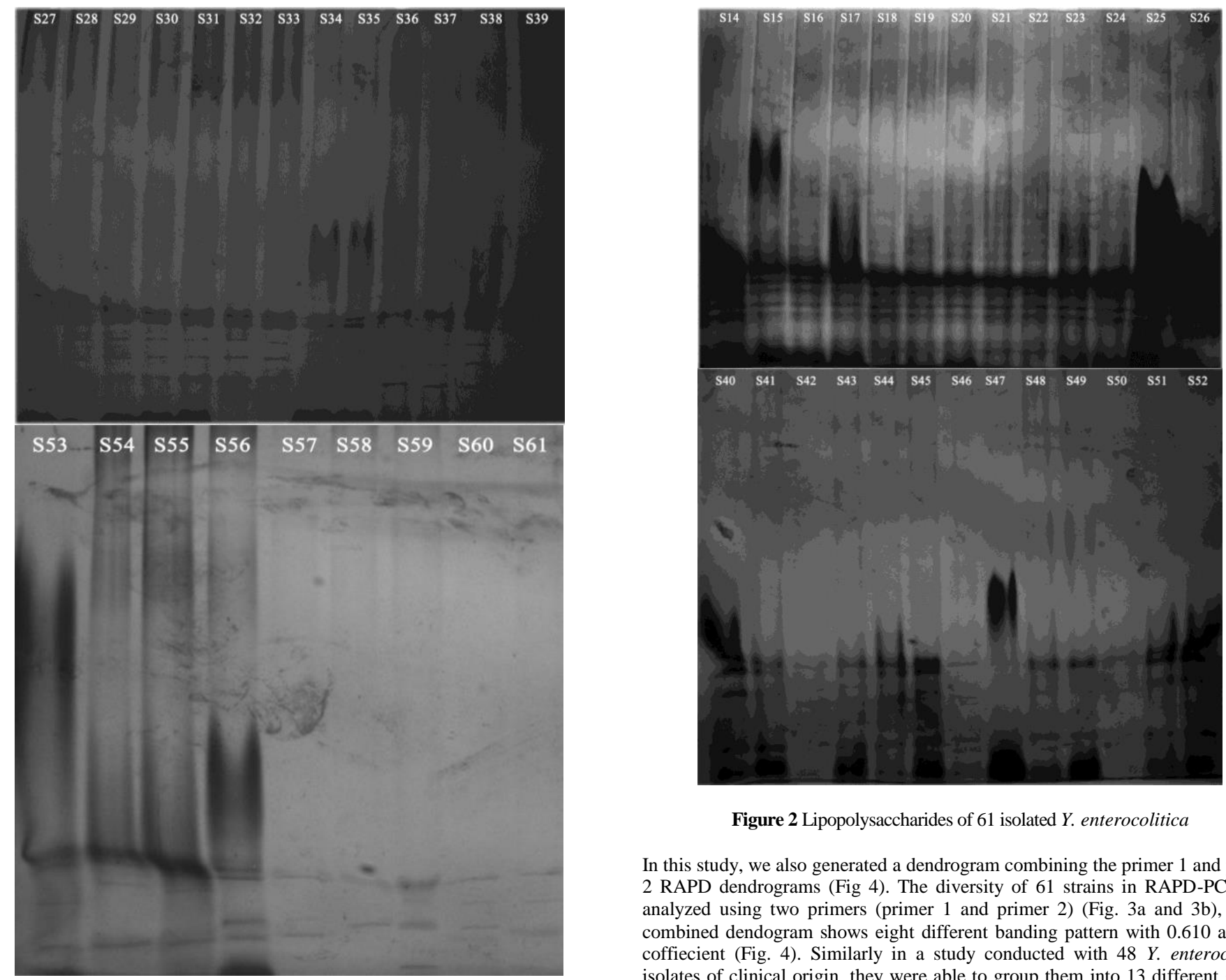

Figure 2 Lipopolysaccharides of 61 isolated $Y$. enterocolitica

In this study, we also generated a dendrogram combining the primer 1 and primer 2 RAPD dendrograms (Fig 4). The diversity of 61 strains in RAPD-PCR was analyzed using two primers (primer 1 and primer 2) (Fig. 3a and 3b), which combined dendogram shows eight different banding pattern with 0.610 average coffiecient (Fig. 4). Similarly in a study conducted with $48 \mathrm{Y}$. enterocolitica isolates of clinical origin, they were able to group them into 13 different groups (Odinot et al., 1995). In another study, it was analyzed with the same primer, the genetic diversity of $20 \mathrm{Y}$. enterocolitica isolated from human and swine sources and found five different genotypic profiles among them (Leal et al., 1999). All the OMP, LPS and RAPD-PCR profiles further confirm the wide genetic diversity among the strains tested.
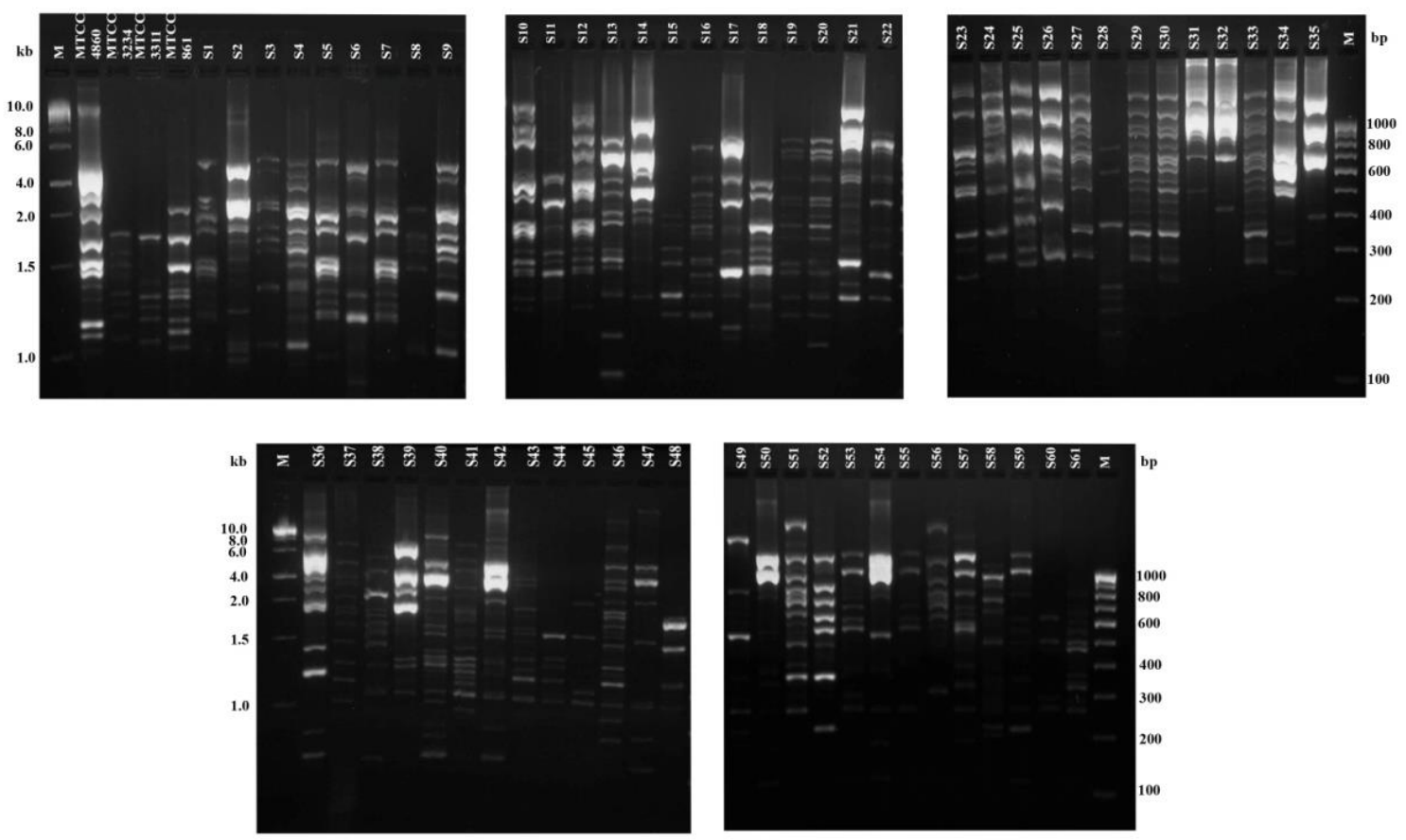

Figure 3a Amplification efficiency of Primer 1 for RAPD-PCR for $Y$. enterocolitica isolates 

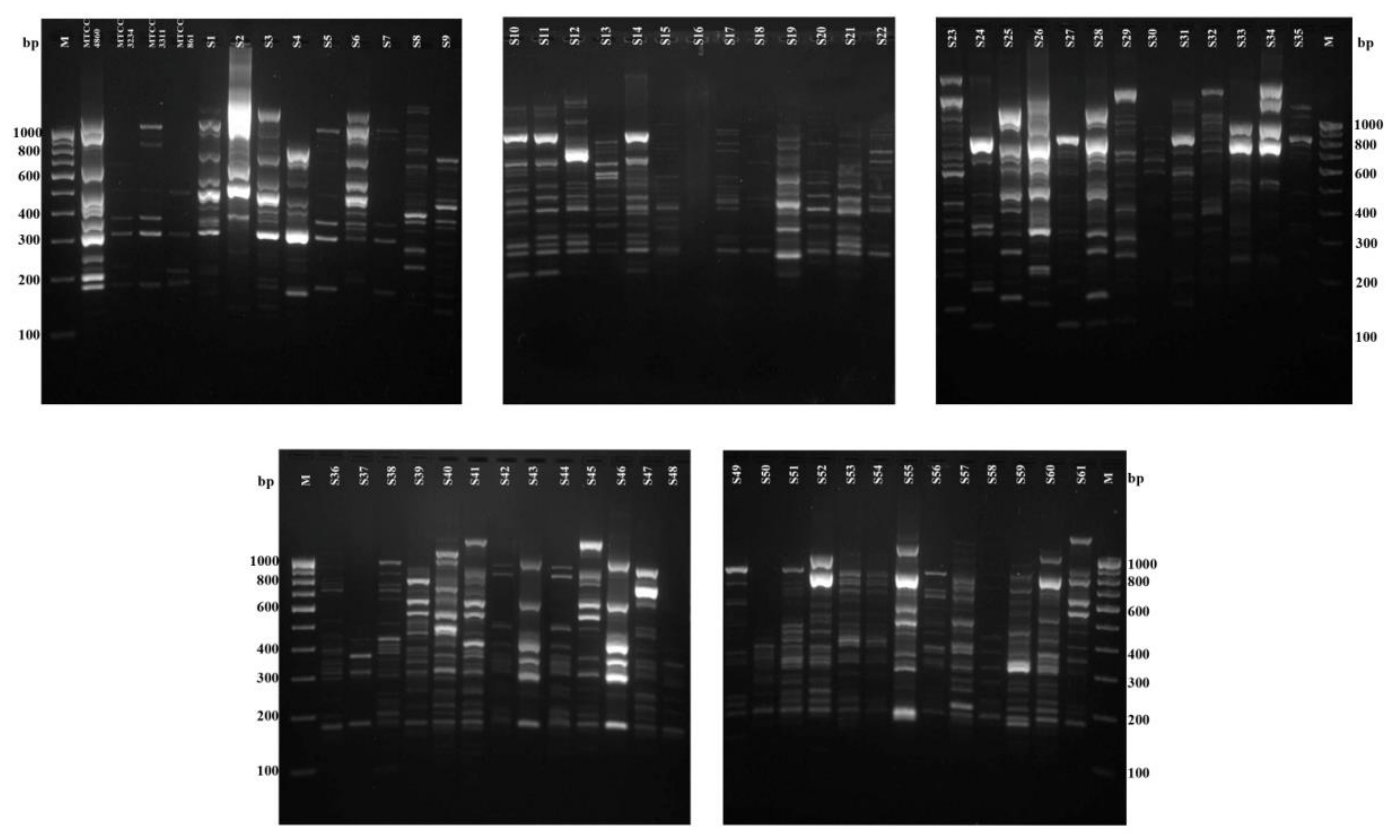

Figure 3b Amplification efficiency of Primer 2 for RAPD-PCR for $Y$. enterocolitica isolates

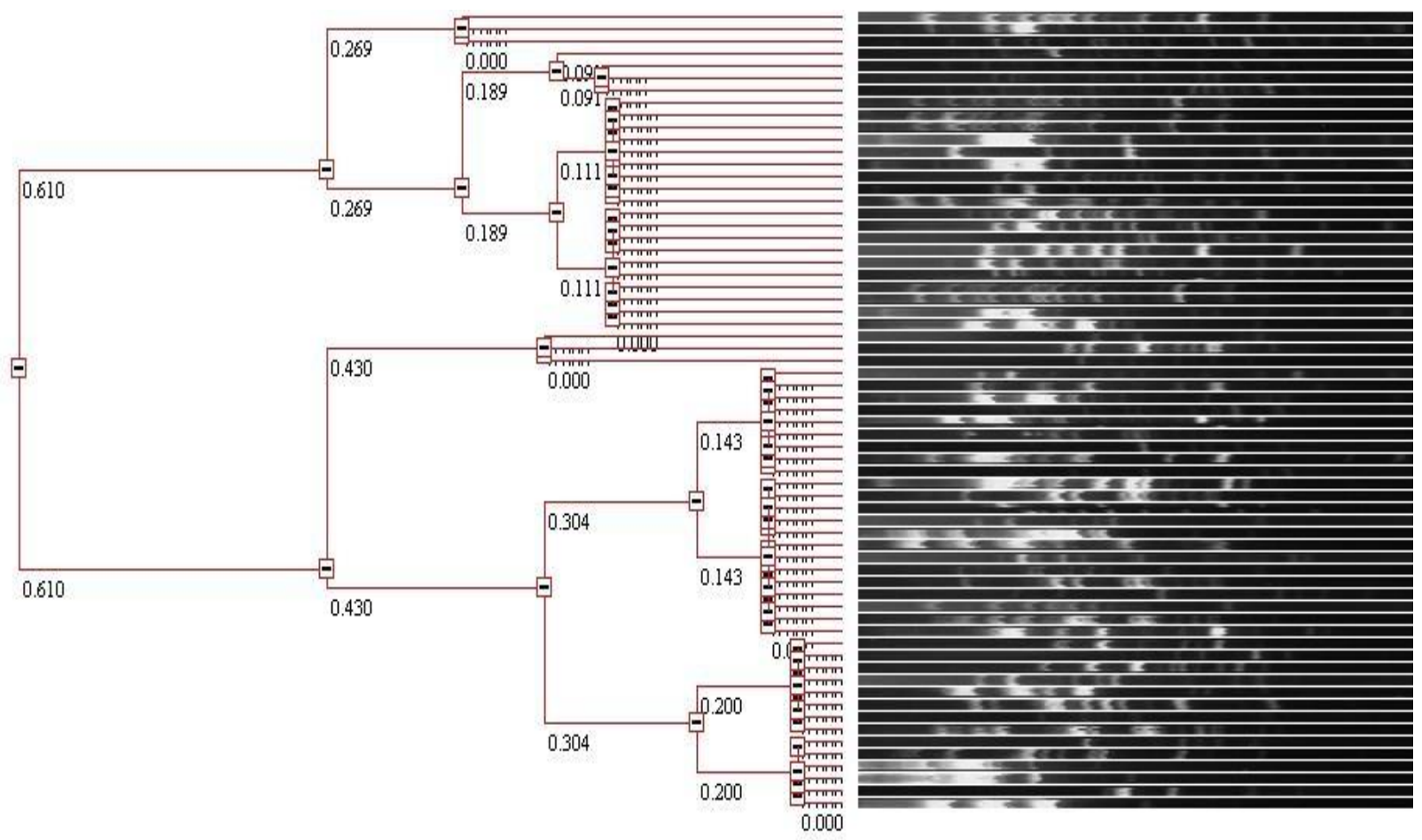

Figure 4 Combined dendrogram for RAPD-PCR (amplified by two different primers) for $Y$. enterocoliticausing simple-match similarity matrix clustered by the unweighted pair-group with arithmetic mean

\section{CONCLUSION}

Based on the previous and current reports, it is very clear that none of the $Y$. enterocolitica isolate is having identical pattern for antibiotic resistance. It varies from source, time and locations, which is based on the resistant genes present in them. This strongly supports the significant impact of geographical location, local selective pressure and other factors in the determination of antibiotic resistance among the $Y$. enterocolitica isolates. This report is an alarm to the public health authorities. Depends on the type of MAR index valve, we may go for the further treatment. Interestingly, all the three tools have proved their ability in differentiating the isolates of $Y$. enterocolitica in this study. In conclusion, we strongly recommend using these typing techniques in the epidemiological investigations with special reference to $Y$. enterocolitica also.
Acknowledgments: The authors thank to the Management of Dr. G.R. Damodaran College of Science for providing necessary facilities and permission to carry out the work in the Department of Biotechnology.

\section{REFERENCES}

BAUER, A.M., KIRBY, W.M.M., SHERRIS, J.C., TURCK, M. 1966. Antibiotic susceptibility testing by a standardized single disk method. American Journal of Clinical Pathology, 45, 493-496.

BLISKA, J.B., GUAN, K., DIXON, J.E., FALKOW, S. 1991. Tyrosine phosphate hydrolysis of host proteins by an essential Yersinia virulence determinant. Proceedings of the National Academy of Sciences, 88, 1189-1191 BOTTONE, E.J. 1977. Yersinia enterocolitica: A panoramic view of a charismatic microorganism. CRC Critical Reviews in Microbiology, 5, 211-241. BOTTONE, E.J. 1983. Current trends of Yersinia enterocolitica isolates in the New York City area. Journal of Clinical Microbiology, 17, 63-67. 
BOYCE, J.M., EVANS, J.R., EVANS, D.G., DUPONT, H.L. 1979. Production of heat-stable, methanol-soluble enterotoxin by Yersinia enterocolitica. Infection and Immunity, 25, 532-537

DUARTE M, SANTOS J, MELO L. 1999. Comparison of similarity coefficients based on RAPD markers in the common bean. Genetics and Molecular biology $22,427-432$

EDEN, K.V., ROSENBERG, M. L., STOOPLER, M., WOOD, B., HIGHSMITH, A. K., SKALIY, P., WELLS J., FEELEY, J. C. 1977. Waterborne gastroenteritis at a ski resort associated with the isolation of Yersinia enterocolitica. Public Health Reports, 92, 245-250.

EZEKIEL, C.N., OLARINMOYE, A.O., OYINLOYE, J.M.A., OLAOYE, O.B., EDUN, A.O. 2011. Distribution, antibiogram and multidrug resistance in Enterobacteriaceae from commercial poultry feeds in Nigeria. African journal of microbiology research, 5(3), 294-301.

FALCAO, J.P., BROCCHI, M., PROENCA-MODENA, J.L., ACRANI, G.O. CORREA, E.F., FALCAO, D.P. 2004. Virulence characteristics and epidemiology of Yersinia enterocolitica and Yersiniae other than $Y$ pseudotuberculosis and $Y$. pestis isolated from water and sewage. Journal of Applied Microbiology, 96, 1230-1236.

FRANCIS, D.W., SPAULDING, P.L., L-VITIT, J. 1980. Enterotoxin production and thermal resistance of Yersinia enterocolitica in milk. Applied Environmental Microbiology, 40, 174-176.

FRANZIN, L., FANTINO, P., VALERIO, V. 1984. Isolation of Yersinia enterocolitica and Yersinia like Organisms from Raw Milk in Italy. Current Microbiology, 10, 357-360.

GEMSKI, P., LAZERE, J.R., CASEY, T. 1980. Plasmid associated with pathogenicity and calcium dependency. Infection and Immunity, 27, 682-685

HAMAMA, A., MARRAKCHI, A., OTHMANI, F. 1992. Occurrence of Yersini enterocolitica in milk and dairy products in Morocco. International Journal of Food Microbiology, 16(1), 69-77.

HOFFMAN, J., LINDBERG, B., BRUBAKER, R.R. 1980. Structural studies of the O-specific side-chains of the lipopolysaccharide from Yersinia enterocolitica Ye 128. Carbohydrate Research, 78, 212-214

KAWAOKA, Y., WAUTERS, G., OTSUKI, K., TSUBOKURA, M. 1986 Identification of Yersinia enterocolitica O15 lipopolysaccharide as a rough antigen. Journal of clinical microbiology, 24(2), 272-4.

KEET, E. E. 1974. Yersinia enterocolitica septicemia. New York State journal of medicine, 74, 2226-2230.

KUZNETSOV, V.G., TIMCHENKO, N.F. 1998. Interactions between bacteria of the genus Yersinia in a water environment. Zhurnal Mikrobiologii, Epidemiologii I Immunobiologii, 6, 26-29.

KWAGA, J.K.P., IVERSEN, J.O. 1992. Laboratory investigation of virulence among strains of Yersinia enterocolitica and related species isolated from pigs and pork products. Canadian Journal of Microbiology, 38, 92-97.

LAEMMLI, U.K. 1970. Cleavage of structural proteins during the assembly of the head of bacteriophage T4. Nature (London) 227, 680-685

LANGELAND, G. 1983. Yersinia enterocolitica and Yersinia-like bacteria in drinking water and sewage sludge. Acta. Pathologica Microbiologica Scandinavica Series B: Microbiology, 91, 179-185.

LEAL, T.A., NILMA, C., ALZIRA, M., ALMEIDA, P. 1999. RAPD-PCR Typing Of Yersinia enterocolitica (Enterobacteriaceae) O:3 Serotype Strains Isolated From Pigs And Humans. Genetics and Molecular Biology, 22(3), 315319

MASSA, S., CESARONI, D., PODA, G., TORVATELLI, L.D. 1988. Isolation of Yersinia enterocolitica and related species from river water. Zentralblatt für Mikrobiologie, 143, 575-581.

MICHIELS, T., WATTIAU, P., BRASSEUR, R. 1990. Secretion of Yop protein by Yersiniae. Infection and Immunity, 58, 2840-9

NEUBAUER, H., HENSEL, A., ALEKSIC, S., MEYER, H. 2000. Identification of Yersinia enterocolitica within the genus Yersinia. Systematic and Applied Microbiology, 23, 58-62.

ODINOT, P,T., MEIS, J.F.G., VAN DEN HURK, P.J.J.C., HOOGKAMP, J.A.A., MELCHERS, W.J.G. 1995. PCR-based characterization of Yersinia enterocolitica: comparison with biotyping and serotyping Epidemniology and Infection, 115, 269-277.

OKWARI, A.E.J., AGADA, G.O.E., OLABODE, A.O., AGINA, S.E., OKPE, E.S., OKOPI, J. 2007. The prevalence of pathogenic Yersinia enterocolitica among diarrhea patients in Jos, Nigeria. African Journal of Biotechnology, 6 , 1031-1034

PAI, C.H., MORS, V. 1978. Production of enterotoxin by Yersinia enterocolitica. Infection and Immunity, 19:908-911

PHILLIPS, I., CASEWELL, M., COX, T., DE GROOT, B., FRIIS, C., JONES, R., NIGHTINGALE, C., PRESTON, R., WADDELL, J. 2004. Does the use of antibiotics in food animals pose a risk to human health? A critical review of published data. Journal of Antimicrobial Chemotherapy, 23, 28-52.

REZANIA, S., AMIRMOZAFFARI, N., TABARRAEI, B., JEDDI-TEHRANI, M., ZAREI, O., ALIZADEH, R., MASJEDIAN, F., ZARNANI, A.H. 2011 Extraction, Purification and Characterization of Lipopolysaccharide from Escherichia coli and Salmonella typhi. The Avicenna Journal of Medical Biotechnology, 3, 3-9.
RUHLE, C., HOLLER C., GUNDERMMAN, K. 1990. Quantitative and qualitative studies of Yersinia species in the waste water of a purification plant. Zentralblatt für Hygiene und Umweltmedizin, 189, 285-299.

SAITOU N, NEI M. 1987. The neighbor-joining method: a new method for reconstructing phylogenetic trees. Molecular Biology Evolution, 4 406-425

YAZDI, S., M.K., SOLTAN-DALLAL, M.M., ZALI, M.R., AVADISIANS, S., BAKHTIARI, R. 2011. Incidence and antibiotic susceptibilities of Yersinia enterocolitica and other Yersinia species recovered from meat and chicken in Tehran, Iran. African journal of microbiology research, 5(18), 2649-2653.

SHAYEGANI, M., DE FORGE, MCGLYNN, D.M., ROOT, T. 1983 Characteristics of Yersinia enterocolitica and related species isolated from human, animal, and environmental sources. Journal of Clinical Microbiology, $14,304-312$

SCHIEMANN, D.A. 1978. Association of Yersinia enterocolitica with the manufacture of cheese and occurrence in pasteurized milk. Applied and Environmental Microbiology, 36, 274-277.

SCHUBERT, S., RAKIN, A., KARCH, H., CARNIEL, E., HEESEMANN, J. 1998. Prevalence of the "high-pathogenicity island" of Yersinia species among Escherichia coli strains that are pathogenic to humans. Infection and Immunity, $66,480-5$

SINGH, I., VIRDI, J.S. 2004. Production of Yersinia stable toxin (YST) and distribution ofyst genes in biotype 1A strains of Yersinia enterocolitica. Journal of Medical Microbiology, 53, 1065-1068.

STOCK, I., WIEDEMANN, B. 1999. An In-vitro study of the antimicrobial susceptibility of Yersinia enterocolitica and the definition of a database. Journal of Antimicrobial Chemotherapy, 43, 37-45.

SUBHA, B., RAMAKRISHNAN, D., SUGANTHI, V. 2009. Antimicrobial Resistance Pattern of Selected Yersinia enterocolitica Isolates from Raw Cow Milk and Pork Samples of Namakkal District, Tamilnadu, South India. Global Journal of Environmental Research, 3 (3), 169-177.

SZCZUKA, E., KAZNOWSKI, A. 2004. Typing of clinical and environmental Aeromonas sp. strains by random amplified polymorphic DNA PCR, repetitive extragenic palindromic PCR and enterobacterial repetitive intergenic consensus sequence PCR. Journal of Clinical Microbiology, 42, 220-228.

TSAI, C.M., FRASCH, C.E. 1982. Staining of lipopolysaccharide in SDS polyacrylamide gels using silver staining method. Analytical Biochemistry, $119,115-119$

VIDON, D.J.M., DELMAS, C.L. 1981. Incidence of Yersinia enterocolitica in raw milk in Eastern France. Applied and Environmental Microbiology, 4, 355

WINDER, C.L., AL-ADHAM, I.S., ABDEL MALEK, S.M., BUULTJENS, T.E., HORROCKS, A.J., COLLIER, J., 2000. Outer membrane protein shifts in biocide-resistant Pseudomonas aeruginosa PAO1. Journal of Applied Microbiology 89, 289-295

WOJCIECH, L., STARONIEWICZ, Z., JAKUBCZAK, A, UGORSKI, M. 2004 Typing of Yersinia enterocolitica isolates by ITS profiling, REP and ERIC PCR. Journal of Veterinary Medicine, 51, 238-244.

ZHANG, L., RADZIEJEWSKA-LEBRECHT, J., KRAJEWSKA-PIETRASIK, D., TOIVANEN, P., SKURNIK, M. 1997. Molecular and chemical characterization of the lipopolysaccharide O-antigen and its role in the virulence of Yersinia enterocolitica serotype O: 8. Molecular and microbiology, 23, 63-76

ZIEGERT, E., DIESTERWEG, I. 1990. The occurrence of Yersinia

enterocolitica in sewage. Zentralblatt für Mikrobiologie, 145, 367-375. 